\title{
ANALISIS FAKTOR RISIKO PADA PASIEN HEMODIALISIS DI RS-X di JAKARTA
}

\author{
Mawaddati Rahmi' ${ }^{1,}$ Yusi Anggriani ${ }^{2}$, Prih Sarnianto ${ }^{3}$ \\ Magister Farmasi, Universitas Pancasila \\ mawaddatirahmi@gmail.com ${ }^{1}$,yusi1777@univpancasila.ac.id ${ }^{2}$
}

\begin{abstract}
Chronic kidney disease (CKD) is a global health problem with high prevalence and cost. Some of the triggering factors for CKD are modifiable, with the hope of reducing the risk of developing CKD, and reducing the severity of CKD experienced by patients. Most CKD will refer to kidney failure, thus requiring higher costs. One way to overcome this high financing problem is of course by doing early treatment and for that it is necessary to identify risk factors for the disease. The purpose of this study is to identify risk factors for kidney failure, where identifying risk factors for kidney failure is one way to reduce the economic burden that arises due to kidney failure. Some risk factors can be changed, but risk factors are influenced by many factors, where risk factors in one population will be different from other populations. The study used amethod case control with a ratio of 1:1, where primary data were obtained through direct interviews with patients and/or their families. Based on logistic regression analysis, the results of factors related to hemodialysis were age $(O R=17.175$, $p$-value $=0.006)$, history of disease $(O R=1248.87, p$-value $=0.000)$, consumption of drugs/herbs with cespleng effect $(O R=23.2, p$-value $=0.001)$, daily water consumption $(O R=10.6, p$-value $=0.004)$, risky drinking habits $(O R=19.1, p$-value $=0.029)$, drinking water sources $(O R=6.24, \quad p$-value $=0.036)$, and consumption of foods high in salt $($ OR=0.056, p-value=0.033). Conclusion: The main factors that trigger hemodialysis in $R S-X$ are patients with a history of diseases such as diabetes, hypertension and heart disorders.
\end{abstract}

Keyword : : Hemodialysis, Risk Factors, Chronic Kidney Disease

\begin{abstract}
ABSTRAK
Penyakit ginjal kronik (PGK) merupakan masalah kesehatan global dengan prevalensi dan biaya yang tinggi. Beberapa faktor pemicu PGK bersifat dapat dirubah, dengan harapan untuk menurunkan risiko terjadinya PGK, dan menurunkan tingkat keparahan PGK yang dialami pasien. Kebanyakan PGK akan mengacu pada kegagalan ginjal, sehingga membutuhkan pembiayaan yang akan semakin tinggi. Salah satu cara untuk mengatasi masalah pembiayaan yang tinggi ini tentunya dengan melakukan penanganan dini dan untuk itu perlu mengidentifikasi faktor risiko dari penyakit tersebut. Tujuan dari penelitian ini adalah untuk untuk mengidentifikasi faktor-faktor risiko gagal ginjal, dimana mengidentifikasi faktor risiko gagal ginjal merupakan salah satu cara untuk mengurangi beban ekonomi yang muncul karena penyakit gagal ginjal. Beberapa faktor risiko dapat diubah, akan tetapi faktor risiko dipengaruhi oleh banyak faktor, dimana faktor risiko pada suatu populasi akan berbeda dari populasi lainnya. Penelitian menggunaan metoda case control dengan perbandingan 1:1, dimana data primer diperoleh melalui wawancara langsung dengan pasien dan/atau keluarga pasien. Berdasarkan analisis regresi logistik diperoleh hasil faktor yang berkaitan dengan hemodialisis adalah umur $(\mathrm{OR}=17,175$, $\mathrm{p}$-value $=0,006)$, riwayat penyakit $(\mathrm{OR}=1248,87, \mathrm{p}$ value $=0,000)$, konsumsi obat/jamu dengan efek cespleng $(\mathrm{OR}=23,2, \mathrm{p}$-value $=0,001)$, konsumsi air dalam sehari $(\mathrm{OR}=10,6$, $\mathrm{p}$-value $=0,004)$, kebiasaan minum berisiko $(\mathrm{OR}=19,1, \mathrm{p}$-value $=0,029)$, sumber air minum $(\mathrm{OR}=6,24, \mathrm{p}$-value $=0,036)$, dan konsumsi makanan tinggi garam $(\mathrm{OR}=0,056, \mathrm{p}$-value $=0,033)$. Kesimpulan: faktor utama pencetus hemodialisis di RS-X adalah pasien dengan riwayat penyakit seperti diabetes, hipertensi dan kelainan jantung.
\end{abstract}

Kata Kunci : Hemodialisis, Faktor Risiko, Penyakit Ginjal Kronik 


\section{PENDAHULUAN}

Menurut Indonesian Renal Registry (IRR) 2017, jumlah pasien baru hemodialisis terus meningkat dari tahun ke tahun dimana tercatat untuk tahun 2015, jumlah pasien baru dan pasien aktif hemodialisis adalah 21.050 dan 30.554. Angka tersebut meningkat 2 dan 5 kali lipat apabila dibandingkan pendataan IRR di tahun 2010. Kemudian terjadi peningkatan yang sigifikan pada tahun 2016 dan 2017. Jumlah pasien baru yang menjalani hemodalisis mencapai 30.831 dengan jumlah pasien aktif sebanyak 77.892. Peningkatan tersebut mencapai 1,5 kali dan 2,6 kali dibandingkan dengan pada tahun 2015. Peningkatan jumlah pasien aktif menunjukkan bahwa hemodialisis mampu memperpanjang umur pasien PGK (10th Report of Indonesan renal registry, Indonesia, 2017). Pada tahun 2017, IRR 2017 melaporkan laki-laki memiliki kecendrungan lebih besar mengalami PGK dibandingkan dengan perempuan, dengan rentang usia diatas 45 tahun lebih aktif menjalani hemodialisis sebanyak $72 \%$ dari total pasien aktif. Penyakit yang menjadi faktor risiko terbesar adalah hipertensi, diabetes nefropati dan penyakit kardiovaskular (10th Report of Indonesan renal registry, Indonesia, 2017).

Di Indonesia, perawatan untuk penyakit ginjal merupakan ranking kedua pembiayaan terbesar dari BPJS Kesehatan setelah penyakit jantung (Infodatin, 2017). Faktor risiko dipengaruhi oleh demografis, stasus sosial ekonomi, kondisi biomedik serta kebiasaan atau prilaku seseorang. Dengan demikian, faktor risiko pada satu populasi akan berbeda dengan fakor risiko pada populasi lainnya. Faktor risiko yang berhubungan dengan kebiasaan dan prilaku seseorang merupakan faktor risiko yang dapat diubah, sedangkan faktor risiko yang berhubungan dengan kondisi medis seseorang adalah faktor risiko yang tidak dapat diubah.
Faktor risiko dapat diubah artinya faktor tersebut dapat diperbaiki/dihindari, sehingga dapat menurunkan risiko terjadinya gagal ginjal, atau setidaknya dapat memperlambat keparahan kerusakan ginjal.

Natalie Alencar, dkk dalam penelitian berdasarkan analisis regresi statistik menyebutkan bahwa faktor yang memiliki hubungan erat denga terjadinya PGK adalah usia, hipertensi, diabetes, dan kegagalan jantung kognitif. Prevalensi meningkat pada pasien rawat inap dengan penyakit yang kompleks seperti usia yang lebih tua, sehingga mereka memiliki komorbiditas lebih banyak dan mencerminkan risiko yang lebih besar untuk mengalami PGK.

Delima, dkk dalam penelitiannya terkait studi kasus kontrol di 4 rumah sakit di Jakarta mengemukakan bahwa faktor risiko terbanyak gagal ginjal adalah : usia lanjut, riwayat keluarga dengan PGK, konsumsi air minum yang $\leq 2000 \mathrm{ml} /$ hari, konsumsi minuman bersoda, konsumsi minuman berenergi, pernah didiagnosis gangguan GFR, batu ginjal, hipertensi dan diabetes melitus. Faktor risiko paling dominan adalah kebiasaan mengkonsumsi minuman berenergi dan minuman bersoda.

Penelitian ini dilakukan untuk mengidentifikasi faktor-faktor risiko gagal ginjal, dimana mengidentifikasi faktor risiko gagal ginjal merupakan salah satu cara untuk mengurangi beban ekonomi yang muncul karena penyakit gagal ginjal. Beberapa faktor risiko dapat diubah, akan tetapi faktor risiko dipengaruhi oleh banyak faktor, dimana faktor risiko pada suatu populasi akan berbeda dari populasi lainnya.

\section{METODE}

Penelitian ini dilakukan untuk mengetahui faktor risiko dengan perbandingan case: control $=100: 100$ dan diambil dari pasien rawat jalan di RS-X Jakarta. Data primer diperoleh dari wawancara langsung dengan 
pasien dan/atau keluarga pasien pada Mei s/d Agustus 2018. Analisis dilakukan hingga tingkat Analisa multivariat untuk mendapatkan gambaran faktor risiko yang paling berpengaruh terhadap PGK pada pasien hemodialisis di RS-X Jakarta.

\section{HASIL}

\section{Analisa Univariat}

Analisis univariat digunakan untuk melihat gambaran secara umum berdasarkan distribusi frekuensi. Secara umum dapat dikelompokkan menjadi 2 kelompok besar, yaitu faktor risiko yang tidak dapat diubah dan yang dapat diubah. Faktor risiko yang tidak dapat diubah terdiri dari faktor sosiodemografi dan faktor predisposisi seperti umur, jenis kelamin, riwayat keluarga dan genetik. Faktor lain seperti faktor biomedik dan faktor prilaku merupakan kelompok faktor yang dapat diubah (Australian Institute of Health and Welfare, 2005).

Berikut merupakan karakteristik sosiodemografi pasien yang dapat dilihat pada jenis tabel 1.

Tabel 1. Distribusi Frekuensi Faktor Risiko Yang Tidak Dapat Diubah Berdasarkan Karakteristik Pasien

\begin{tabular}{|c|c|c|c|c|c|c|}
\hline \multirow{2}{*}{ Karakteristik } & \multicolumn{2}{|c|}{$\operatorname{Kasus}(\mathbf{n})$} & \multicolumn{2}{|c|}{ Kontrol(n) } & \multicolumn{2}{|c|}{ Total } \\
\hline & $\mathbf{n}$ & $\%$ & $\mathbf{n}$ & $\%$ & $\mathbf{n}$ & $\%$ \\
\hline \multicolumn{7}{|l|}{ Umur } \\
\hline$<30$ & 14 & 14 & 38 & 38 & 52 & 26 \\
\hline $30-39$ & 25 & 25 & 16 & 16 & 41 & 20.5 \\
\hline $40-49$ & 24 & 24 & 18 & 18 & 42 & 21 \\
\hline $50-59$ & 28 & 28 & 22 & 22 & 50 & 25 \\
\hline$>=60$ & 9 & 9 & 6 & 6 & 15 & 7.5 \\
\hline \multicolumn{7}{|l|}{ Jenis Kelamin } \\
\hline Laki-laki & 52 & 52 & 47 & 47 & 99 & 49.5 \\
\hline Perempuan & 48 & 48 & 53 & 53 & 101 & 50.5 \\
\hline \multicolumn{7}{|l|}{ Status Perkawinan } \\
\hline Belum Pernah Kawin & 12 & 12 & 15 & 15 & 27 & 13.5 \\
\hline Kawin & 84 & 84 & 83 & 83 & 167 & 83.5 \\
\hline Janda/Duda & 4 & 4 & 2 & 2 & 6 & 3 \\
\hline \multicolumn{7}{|l|}{ Pendidikan } \\
\hline Tidak Sekolah & 2 & 2 & 2 & 2 & 4 & 2 \\
\hline Sekolah Dasar & 9 & 9 & 22 & 22 & 31 & 15.5 \\
\hline Sekolah Menengah & 64 & 64 & 68 & 68 & 132 & 66 \\
\hline Akademi/Universitas & 25 & 25 & 8 & 8 & 33 & 16.5 \\
\hline \multicolumn{7}{|l|}{ Pekerjaan } \\
\hline Membutuhkan otak & 11 & 11 & 4 & 4 & 15 & 7.5 \\
\hline Membutuhkan otot & 60 & 60 & 62 & 62 & 122 & 61 \\
\hline Di rumah/pensiunan & 29 & 29 & 34 & 34 & 63 & 31.5 \\
\hline
\end{tabular}




\begin{tabular}{|c|c|c|c|c|c|c|}
\hline \multirow{2}{*}{ Karakteristik } & \multicolumn{2}{|c|}{$\operatorname{Kasus}(n)$} & \multicolumn{2}{|c|}{ Kontrol(n) } & \multicolumn{2}{|c|}{ Total } \\
\hline & $\mathbf{n}$ & $\%$ & $\mathbf{n}$ & $\%$ & $\mathbf{n}$ & $\%$ \\
\hline$<3 \mathrm{jt}$ & 56 & 56 & 54 & 54 & 110 & 55 \\
\hline $3 \mathrm{jt}-5 \mathrm{jt}$ & 21 & 21 & 28 & 28 & 49 & 24.5 \\
\hline $5 \mathrm{jt}$ & 13 & 13 & 6 & 6 & 19 & 9.5 \\
\hline Tidak tahu & 10 & 10 & 12 & 12 & 22 & 11 \\
\hline TOTAL & 100 & 100 & 100 & 100 & 200 & 100 \\
\hline
\end{tabular}

Umur terkecil yang masuk dalam penelusuran yaitu 18 tahun dan yang tertua usia 66 tahun. Berdasarkan tabel di atas, terlihat bahwa kelompok umur di atas 30 lebih mendominasi dibanding dengan di bawah 30 tahun. Berdasarkan jenis kelamin, kelompok yang sama-sama dominan adalah pekerjaan yang membutuhkan kekuatan fisik/otot (60\% dan 62\%). Berdasarkan kelompok pendapatan, 55\% responden memiliki pendapatan di bawah 3 juta, dan hanya 9,5\% saja yang memiliki pendapatan di atas 5 juta. Karakterisktik terkait prilaku atau kebiasaan seperti merokok, konsumsi obat dan jamu, makanan, sumber air minum dan minuman lainnya, serta penyakit komorbiditas termasuk ke dalam faktor risiko yang dapat diubah dengan kategori berikut :

Tabel 2. Distribusi Frekuensi Faktor Risiko yang dapat diubah berdasarkan karakteristik pasien

\begin{tabular}{|c|c|c|c|c|c|c|}
\hline \multirow{2}{*}{ Karakteristik } & \multicolumn{2}{|c|}{ Kasus } & \multicolumn{2}{|c|}{ Kontrol } & \multicolumn{2}{|c|}{ Total } \\
\hline & $\mathbf{n}$ & $\%$ & $\mathbf{N}$ & $\%$ & $\mathbf{n}$ & $\%$ \\
\hline \multicolumn{7}{|l|}{ Riwayat Penyakit Berisiko } \\
\hline Ada & 91 & 91 & 11 & 11 & 102 & 51 \\
\hline Tidak Ada & 9 & 9 & 89 & 89 & 98 & 49 \\
\hline \multicolumn{7}{|l|}{ Gejala Sebelum Hemodalisis } \\
\hline Ada & 8 & 8 & 1 & 1 & 9 & 4.5 \\
\hline Tidak Ada & 92 & 92 & 99 & 99 & 191 & 95.5 \\
\hline \multicolumn{7}{|l|}{ Riwayat Konsumsi Obat/Jamu } \\
\hline Efek cepat & 39 & 39 & 14 & 14 & 53 & 26.5 \\
\hline Tidak & 61 & 61 & 86 & 86 & 147 & 73.5 \\
\hline \multicolumn{7}{|l|}{ Kebiasaan Minum Berisiko } \\
\hline Kurang Baik & 97 & 97 & 93 & 93 & 190 & 95 \\
\hline Baik & 3 & 3 & 7 & 7 & 10 & 5 \\
\hline \multicolumn{7}{|l|}{ Konsumsi Makanan Tinggi Garam } \\
\hline Ya & 7 & 7 & 4 & 4 & 11 & 5.5 \\
\hline Tidak & 93 & 93 & 96 & 96 & 189 & 94.5 \\
\hline \multicolumn{7}{|c|}{ Konsumsi Makanan Tinggi Garam dan Lemak } \\
\hline Ya & 89 & 89 & 93 & 93 & 182 & 91 \\
\hline Tidak & 11 & 11 & 7 & 7 & 18 & 9 \\
\hline
\end{tabular}




\begin{tabular}{llllllll}
\hline \multirow{2}{*}{ Karakteristik } & \multicolumn{2}{c}{ Kasus } & \multicolumn{2}{c}{ Kontrol } & \multicolumn{2}{c}{ Total } \\
\cline { 2 - 7 } & $\mathbf{n}$ & $\%$ & $\mathbf{N}$ & $\%$ & n & $\%$ \\
\hline
\end{tabular}

Konsumsi Daging Olahan

\begin{tabular}{lllllll}
\hline Ya & 74 & 74 & 83 & 83 & 157 & 78.5 \\
\hline Tidak & 26 & 26 & 17 & 17 & 43 & 21.5 \\
\hline
\end{tabular}

\begin{tabular}{ccccccc} 
Konsumsi Air dalam Sehari & & & & & & \\
\hline 1-4 gelas & 17 & 17 & 14 & 14 & 31 & 15.5 \\
\hline 5-8 gelas & 43 & 43 & 33 & 33 & 76 & 38 \\
\hline$>8$ gelas & 40 & 40 & 53 & 53 & 93 & 46.5 \\
\hline Sumber Air Minum & & & & & & \\
\hline Air Sumur & 73 & 73 & 77 & 77 & 150 & 75 \\
\hline Bukan Air Sumur & 27 & 27 & 23 & 23 & 50 & 25 \\
\hline
\end{tabular}

Merokok

\begin{tabular}{lcccccc}
\hline Merokok Aktif & 21 & 21 & 28 & 28 & 49 & 24.5 \\
\hline Tidak Merokok & 49 & 49 & 62 & 62 & 111 & 55.5 \\
\hline Pernah (sudah berhenti) & 30 & 30 & 10 & 10 & 40 & 20 \\
\hline TOTAL & $\mathbf{1 0 0}$ & $\mathbf{1 0 0}$ & $\mathbf{1 0 0}$ & $\mathbf{1 0 0}$ & $\mathbf{2 0 0}$ & $\mathbf{1 0 0}$ \\
\hline
\end{tabular}

Sebanyak $51 \%$ dari responden memilki riwayat penyakit sebelum mereka terdiagnosa penyakit yang saat ini tengah di hadapi. Pada kasus hemodialisis, hanya $4,5 \%$ responden yang pernah mengalami gejala-gejala yang menunjukkan risiko gagal ginjal, dan hanya $8 \%$ pada kelompok kontrol yang menunjukkan gelaja gagal ginjal. Hal ini terjadi karena pada tahap awal, PGK belum menimbulkan gejala dan tanda-tanda, bahkan setelah laju filtrasi glomerulus sebesar $60 \%$ pasien masih asimtomatik. Kelainan secara klinis dan laboratorium akan mulai terlihat pada PGK tahap 3 dan 4, dan pada tahap 4 laju filtras glomerulus sudah mulai berkurang hingga $30 \%$. Sebagian pasien sudah mengalami fase gagal ginjal dan membutuhkan terapi hemodialisis pada tahapan ini (Infodatin, 2017).

Kebiasaan terkait penggunaan obat dan mengkonsumsi jamu dengan efek cespleng mencapai angka 39\% pada kelompok kasus, dan $14 \%$ pada kelompok kontrol. Hal ini berkaitan dengan riwayat penyakit dimana responden memerlukan obat atau suplemen lain untuk mengatasi penyakit dan menjaga kesehatannya.
Kebiasaan minum beresiko yang kurang baik pada kedua kelompok 95\%. Data menunjukkan kebiasaan responden untuk minum minuman bersoda, minuman isotonis, minuman berenergi, minuman beralkohol dan minuman lain seperti kopi, teh, dan coklat. Disamping itu, $15.5 \%$ responden mengalami kekurangan minum (14 gelas) setiap harinya. Hanya $40 \%$ dan $53 \%$ dari kelompok kasus dan responden yang minum air lebih dari 8 (delapan) gelas per hari. Sumber air minum kebanyakan dari air sumur, hanya $25 \%$ saja yang minum air yang bukan dari air sumur, melainkan air kemasan, isi ulang atau air ledeng.

Berdasarkan kebiasaan makan, konsumsi makanan tinggi garam dan lemak menjadi favorit responden dengan persentase kelompok kasus dan kontrol $89 \%$ dan 93\%. Data ini melebihi data riskesdas 2013 yang menyebutkan masyarakat Indonesia sebanyak $40.7 \%$ mengkonsumsi makanan berisiko yang mengandung lemak berlebih, berkolesterol dan gorengan lebih dari satu kali perhari (Badan Penelitian dan Pengembangan Kesehatan, 2017). Konsumsi daging olahan juga mencapai angka $74 \%$ dan $83 \%$ 
pada kelompok kasus dan kontrol, dan hanya 5.5\% saja yang suka menambahkan garam pada saat makan.

Kebiasaan lainnya yang perlu diperhatikan adalah kebiasaan merokok, karena pada penelitian sebelumnya telah di teliti bahwa kebiasaan merokok memiliki hubungan dengan terjadinya gagal ginjal (Indonesia Investment, 2019). Pada penelitian ini diperoleh $51 \%$ kelompok kasus memilki kebiasaan merokok, walaupun $30 \%$ sudah behenti dan $21 \%$ masih aktif merokok walaupun sudah terdiagnosa gagal ginjal dan harus menjalani hemodialisis. Pada kelompok kontrol sebanyak $62 \%$ tidak merokok, $10 \%$ sudah berhenti merokok, dan $28 \%$ masih merokok aktif hingga wawancara dilakukan.

\section{Analisis Bivariat}

Pada analisis bivariat dilakukan analisis untuk mengetahui faktor-faktor yang berhubungan dengan PGK yang mengakibatkan pasien harus menjalani terapi hemodialisis. Pada tahapan ini setiap variabel independen akan ditabulasi-silang dengan variabel dependen. Pada tabulasi silang $2 \times 2$ akan dicari OR (Odds Ratio) guna mengetahui apakah ada pengaruh antara faktor risiko sebagai variabel independen dengan PGK sebagai variabel dependen.

Variabel analisis tahapan ini berdasarkan pada hasil analisis univariat. Variabel yang dianalisis yaitu faktor umur, jenis kelamin, pendidikan, status perkawianan, pekerjaan, kebiasaan merokok, riwayat penyakit, riwayat konsumsi obat/jamu tradisional, kebiasaan mium dan kebiasaan makan pasien. Untuk mengetahui kemaknaan hubungan secara statstik, maka dilakukan analisis statistik, yaitu dengan metode Chi-square dengan hasil sebagai berikut :

\section{Umur}

Berdasarkan hasil analisis diperoleh bahwa pasien dengan kategori umur 30-39 tahun risikonya 4,2 kali untuk menjalani Hemodialisis dibandingkan dengan kelompok umur kurang dari 30 tahun (OR=4,241; 95\% $\mathrm{CI}=1,764-10,195)$. Demikian pula kategori umur $>=60$ tahun risikonya 4 kali untuk menjalani Hemodialisis dibandingkan dengan kelompok umur kurang dari 30 tahun $(\mathrm{OR}=4,071 ; 95 \% \mathrm{CI}=1,225-13,532)$.
Nilai $\mathrm{p}=0,001$ artinya umur memiliki pengaruh signifikan terhadap Hemodialisis.

Usia akan mempengaruhi mempengaruhi anatomi, fisiologi dan sitologi ginjal, sehingga fungsi ginjal. Kemudian sebuah penelitian di Ponorogo menyebutkan bahwa risiko gagal ginjal pada usia diatas 50 tahun mencapai 57\% (Badan Penelitian dan Pengembangan Kesehatan, 2017). Seiring dengan bertambahnya usia, akan terjadi penurunan fungsi ginjal dan itu merupakan hal yang wajar. Penurunan tersebut tidak akan sampai menyebabkan kelainan ataupun gejala gagal ginjal karena masih dalam batas-batas wajar yang dapat ditoleransi oleh tubuh dan ginjal. Akan tetapi, apabila terdapat beberapa faktor risiko lain yang mengikuti, maka dapat terjadi kerusakan ginjal secara progresif yang dapat berakibat pada ketidakmampuan ginjal untuk bekerja. Pada tahap ini gejala akan mulai terlihat, mulai dari keluhan yang bersifat ringan hingga berat.

\section{Analisis Multivariat}

Variabel yang diikutsertakan pada analisis multivariat adalah seluruh variabel penelitian guna mendapatkan hasil yang lebih presisi, sehingga tidak dilakukan seleksi variabel berdasarkan $p$ value nya. Adapun analisis yang dilakukan pada analisis multivariat ini adalah analisis regresi logistik ganda, dengan tahapan sebagai berikut:

\section{Full Model}

Pada tahapan ini dilakukan analisis yang mencakup semua variabel yang diperhitungkan, guna mengetahui variabel mana saja yang memiliki pengaruh signifikan. Hasil analisis Full Mode sebagai berikut:

Tabel 3. Hasil analisis Multivariable Full Model

\begin{tabular}{|c|c|c|c|c|}
\hline \multirow{2}{*}{$\begin{array}{c}\text { Variabel } \\
\text { Independen }\end{array}$} & \multirow{2}{*}{$\begin{array}{l}\text { Odds } \\
\text { Ratio } \\
\end{array}$} & \multicolumn{2}{|c|}{$95 \% \mathrm{CI}$} & \multirow{2}{*}{$\begin{array}{c}P \text { - } \\
\text { value }\end{array}$} \\
\hline & & Lower & Upper & \\
\hline Umur & & & & 0,006 \\
\hline \multirow{2}{*}{ 30-39 tahun } & 18.3 & 1.30 & 257.65 & \\
\hline & 08 & 1 & 4 & \\
\hline \multirow{2}{*}{ 40-49 tahun } & 41.0 & 2.96 & 567.52 & \\
\hline & 20 & 5 & 3 & \\
\hline \multirow{2}{*}{$50-59$ tahun } & 2.43 & 0.26 & \multirow{2}{*}{22.425} & \\
\hline & 8 & 5 & & \\
\hline \multirow{2}{*}{$>=60$ tahun } & 9.92 & 0.35 & 277.40 & \\
\hline & 3 & 5 & 1 & \\
\hline
\end{tabular}




\begin{tabular}{|c|c|c|c|c|}
\hline \multirow{2}{*}{$\begin{array}{c}\text { Variabel } \\
\text { Independen }\end{array}$} & \multirow{2}{*}{$\begin{array}{l}\text { Odds } \\
\text { Ratio }\end{array}$} & \multicolumn{2}{|c|}{$95 \% \mathrm{CI}$} & \multirow{2}{*}{$\begin{array}{c}P- \\
\text { value }\end{array}$} \\
\hline & & Lower & Upper & \\
\hline $\begin{array}{l}\text { Jenis } \\
\text { Kelamin }\end{array}$ & $\begin{array}{r}0.15 \\
3\end{array}$ & $\begin{array}{r}0.01 \\
3\end{array}$ & 1.810 & 0,137 \\
\hline $\begin{array}{l}\text { Status } \\
\text { Perkawinan }\end{array}$ & & & & 0,429 \\
\hline Kawin & $\begin{array}{r}0.36 \\
7\end{array}$ & $\begin{array}{r}0.03 \\
1\end{array}$ & 4.386 & \\
\hline Janda/Duda & $\begin{array}{r}0.21 \\
7\end{array}$ & $\begin{array}{r}0.00 \\
1\end{array}$ & 40.236 & \\
\hline Pendidikan & & & & 0,265 \\
\hline Sekolah & 3.62 & 0.02 & 475.44 & \\
\hline Dasar & 4 & 8 & 7 & \\
\hline $\begin{array}{l}\text { Sekolah } \\
\text { Menengah }\end{array}$ & $\begin{array}{r}10.8 \\
39\end{array}$ & $\begin{array}{r}0.09 \\
7\end{array}$ & $\begin{array}{r}1210.6 \\
12\end{array}$ & \\
\hline $\begin{array}{l}\text { Akademi/Uni } \\
\text { versitas }\end{array}$ & $\begin{array}{r}17.5 \\
19 \\
\end{array}$ & $\begin{array}{r}0.11 \\
4 \\
\end{array}$ & $\begin{array}{r}2699.1 \\
56 \\
\end{array}$ & \\
\hline Pekerjaan & & & & 0,480 \\
\hline $\begin{array}{l}\text { Membutuhka } \\
\text { n otak }\end{array}$ & $\begin{array}{r}0.26 \\
7\end{array}$ & $\begin{array}{r}0.00 \\
7\end{array}$ & 10.391 & \\
\hline $\begin{array}{l}\text { Membutuhka } \\
\text { n otot }\end{array}$ & $\begin{array}{r}0.87 \\
2\end{array}$ & $\begin{array}{r}0.14 \\
6\end{array}$ & 5.204 & \\
\hline $\begin{array}{l}\text { Riwayat } \\
\text { Penyakit }\end{array}$ & $\begin{array}{r}1868 \\
.505 \\
\end{array}$ & $\begin{array}{r}130 . \\
897 \\
\end{array}$ & $\begin{array}{r}26672 . \\
291 \\
\end{array}$ & 0,000 \\
\hline $\begin{array}{l}\text { Gejala } \\
\text { Sebelum } \\
\text { Hemodialisis }\end{array}$ & $\begin{array}{r}4.57 \\
6\end{array}$ & $\begin{array}{r}0.02 \\
8\end{array}$ & $\begin{array}{r}738.08 \\
5\end{array}$ & 0,558 \\
\hline $\begin{array}{l}\text { Riwayat } \\
\text { Konsumsi } \\
\text { Obat/Jamu } \\
\text { Cespleng }\end{array}$ & $\begin{array}{r}25.1 \\
87\end{array}$ & $\begin{array}{r}3.15 \\
2\end{array}$ & $\begin{array}{r}201.27 \\
5\end{array}$ & 0,002 \\
\hline $\begin{array}{l}\text { Konsumsi } \\
\text { Air dalam } \\
\text { Sehari }\end{array}$ & & & & 0,008 \\
\hline $\begin{array}{l}1-4 \text { gelas per } \\
\text { hari }\end{array}$ & $\begin{array}{r}4.51 \\
3 \\
\end{array}$ & $\begin{array}{r}0.54 \\
9 \\
\end{array}$ & 37.092 & \\
\hline $\begin{array}{l}5-8 \text { gelas per } \\
\text { hari }\end{array}$ & $\begin{array}{r}11.6 \\
92\end{array}$ & $\begin{array}{r}1.87 \\
9\end{array}$ & 72.773 & \\
\hline $\begin{array}{l}\text { Kebiasaan } \\
\text { Minum } \\
\text { Berisiko } \\
\end{array}$ & $\begin{array}{r}40.4 \\
49\end{array}$ & $\begin{array}{r}1.46 \\
6\end{array}$ & $\begin{array}{r}1115.8 \\
94\end{array}$ & 0,029 \\
\hline $\begin{array}{l}\text { Sumber Air } \\
\text { Minum }\end{array}$ & $\begin{array}{r}8.55 \\
8\end{array}$ & $\begin{array}{r}1.07 \\
3\end{array}$ & 68.273 & 0,043 \\
\hline $\begin{array}{l}\text { Konsumsi } \\
\text { Makan } \\
\text { Tinggi } \\
\text { Garam } \\
\end{array}$ & $\begin{array}{r}0.04 \\
4\end{array}$ & $\begin{array}{r}0.00 \\
1\end{array}$ & 1.808 & 0,100 \\
\hline $\begin{array}{l}\text { Konsumsi } \\
\text { Makan } \\
\text { Tinggi } \\
\text { Garam dan } \\
\text { lemak }\end{array}$ & $\begin{array}{r}0.36 \\
7\end{array}$ & $\begin{array}{r}0.03 \\
6\end{array}$ & 3.713 & 0,396 \\
\hline
\end{tabular}

\begin{tabular}{lrrrr}
\hline \multicolumn{1}{c}{ Variabel } & Odds & \multicolumn{2}{c}{$\mathbf{9 5 \%}$ CI } & $\begin{array}{c}P \text { - } \\
\text { Independen }\end{array}$ \\
\cline { 3 - 4 } & Ratio & Lower & Upper & value \\
\hline Konsumsi & & & & \\
Makan & 1.54 & 0.22 & 10.679 & 0,661 \\
Daging & 3 & 3 & & \\
Olahan & & & & \\
\hline
\end{tabular}

\section{Final Model}

Tahapan ini merupakan hasil akhir dari eliminasi variabel-variabel non-signifikan dimana variabel dengan $p$-value $>0,25$ dihilangkan, sehingga memunculkan variabel-variabel yang signifikan sebagai berikut :

Tabel 4. Hasil analisis Multivariable Final Model

\begin{tabular}{|c|c|c|c|c|}
\hline \multirow[b]{2}{*}{$\begin{array}{c}\text { Variabel } \\
\text { Independen }\end{array}$} & \multirow[b]{2}{*}{$\begin{array}{l}\text { Odds } \\
\text { Ratio }\end{array}$} & \multicolumn{2}{|c|}{$95 \%$ CI } & \multirow{2}{*}{$\begin{array}{c}P- \\
\text { valu } \\
e\end{array}$} \\
\hline & & $\begin{array}{l}\text { Low } \\
\text { er }\end{array}$ & $\begin{array}{c}\text { Uppe } \\
r\end{array}$ & \\
\hline Umur & & & & $\begin{array}{c}0,00 \\
6\end{array}$ \\
\hline 30-39 tahun & 11.170 & $\begin{array}{r}1.54 \\
1 \\
\end{array}$ & $\begin{array}{r}80.95 \\
7\end{array}$ & \\
\hline 40-49 tahun & 17.175 & $\begin{array}{r}2.30 \\
0 \\
\end{array}$ & $\begin{array}{r}128.2 \\
75 \\
\end{array}$ & \\
\hline 50-59 tahun & 1.406 & $\begin{array}{r}0.27 \\
8\end{array}$ & 7.101 & \\
\hline$>=60$ tahun & 2.715 & $\begin{array}{r}0.19 \\
8 \\
\end{array}$ & $\begin{array}{r}37.24 \\
0 \\
\end{array}$ & \\
\hline Riwayat Penyakit & $\begin{array}{r}1248.8 \\
67 \\
\end{array}$ & $\begin{array}{r}131 . \\
939\end{array}$ & $\begin{array}{r}11821 \\
.093\end{array}$ & $\begin{array}{c}0.00 \\
0\end{array}$ \\
\hline $\begin{array}{l}\text { Riwayat Konsumsi } \\
\text { Obat/Jamu } \\
\text { Cespleng }\end{array}$ & 23.201 & $\begin{array}{r}3.83 \\
6\end{array}$ & $\begin{array}{r}140.3 \\
17\end{array}$ & $\begin{array}{c}0.00 \\
1\end{array}$ \\
\hline $\begin{array}{ll}\begin{array}{l}\text { Konsumsi } \\
\text { dalam Sehari }\end{array} & \text { Air } \\
\end{array}$ & & & & $\begin{array}{c}0,00 \\
4\end{array}$ \\
\hline 1-4 gelas per hari & 5.404 & $\begin{array}{r}0.80 \\
1\end{array}$ & $\begin{array}{r}36.46 \\
3\end{array}$ & \\
\hline 5-8 gelas per hari & 10.645 & $\begin{array}{r}2.11 \\
5\end{array}$ & $\begin{array}{r}53.57 \\
1\end{array}$ & \\
\hline $\begin{array}{l}\text { Kebiasaan Minum } \\
\text { Berisiko }\end{array}$ & 19.079 & $\begin{array}{r}1.34 \\
7 \\
\end{array}$ & $\begin{array}{r}270.2 \\
81 \\
\end{array}$ & $\begin{array}{c}0.02 \\
9\end{array}$ \\
\hline $\begin{array}{l}\text { Sumber } \\
\text { Minum }\end{array}$ & 6.244 & $\begin{array}{r}1.13 \\
2 \\
\end{array}$ & $\begin{array}{r}34.43 \\
8 \\
\end{array}$ & $\begin{array}{c}0.03 \\
6\end{array}$ \\
\hline $\begin{array}{ll}\text { Konsumsi } & \\
\text { Makanan } & \text { Tinggi } \\
\text { Garam } & \end{array}$ & 0.056 & $\begin{array}{r}0.00 \\
4\end{array}$ & 0.798 & $\begin{array}{c}0.03 \\
3\end{array}$ \\
\hline
\end{tabular}

Berdasarkan Tabel 4 terdapat sebanyak 7 (tujuh) faktor dieliminasi dari model karena setelah dianalisis bersama, diperoleh $\mathrm{p}$ value nya lebih dari 0,05 . Berdasarkan hasil analisis 
dengan uji regresi logistik ganda, dapat disimpulkan bahwa faktor yang berkaitan dengan Hemodialisis adalah umur, riwayat penyakit, riwayat konsumsi obat/jamu cespleng, konsumsi air dalam sehari, kebiasaan minum berisiko, sumber air minum, dan konsumsi makanan tinggi garam. Riwayat penyakit memilki nilai Odds Ratio yang sangat besar yang berarti riwayat penyakit memiliki keeretan yang paling kuat terhadap dilakukannya Hemodialisis. Hal ini sesuai dengan penjelasan pada penelitian sebelumnya, bahwa pasien yang memiliki komplikasi penyakit terutama hipertensi, penyakit kardiovaskular, diabetes dan penyakit infeksi saluran kemih memiliki potensi lebih besar menjalani hemodialisis (Natalia Alencar, et al, 2014).

\section{PEMBAHASAN}

\section{Jenis Kelamin}

Berdasarkan hasil analisis diperoleh bahwa pasien laki-laki berisiko 1,2 kali lebih tinggi daripada perempuan untuk menjalani Hemodialisis $\quad(\mathrm{OR}=1,22 ; \quad 95 \% \quad \mathrm{CI}=0,701$ $2,13)$. Nilai $p=0,572$ artinya jenis kelamin tidak memiliki pengaruh terhadap Hemodialisis. Meskipun tidak memiliki pengaruh yang bermakna terhadap PGK, namun hal tersebut sesuai dengan data Riskesdas 2013 yang menyebutkan bahwa laki-laki memiliki risiko yang lebih besar mengalai PGK dari pada perempuan. ${ }^{4}$ Pada penelitian tahun 2015 oleh Restu Pranandari dkk juga menyebutkan bahwa laki-laki berisiko 2 kali lebih besar dari pada perempuan, karena para perempuan biasanya lebih peduli menjaga kesehatannya dari pada laki-laki. ${ }^{7}$ Hal tersebut juga sesuai dengan penelitian di Kanada yang menemukan lakilaki 64\% lebih berpeluang mengalami gagal ginjal dibandingkan perempuan.

\section{Pendidikan}

Berdasarkan hasil analisis diperoleh bahwa pasien yang pendidikan terakhirnya akademi/universitas berisiko 3,1 kali daripada pasien yang tidak sekolah untuk menjalani Hemodialisis $\quad(\mathrm{OR}=3,125 ; \quad 95 \% \quad \mathrm{CI}=0,38$ 25,92 ). Nilai $\mathrm{p}=0,004$ artinya pendidikan memiliki pengaruh signifikan terhadap Hemodialisis. Pada penelitian ini, terlihat bahwa sebagian besar responden berasal dari tingkat pendidikan menengah pada kelompok kasus dan kontrol, yaitu $64 \%$ dan $68 \%$. Kemudian 2\% dari total responden tidak bersekolah dan 15,5\% memiliki pendidikan sampai sekolah dasar saja. Kelompok responden dengan pendidikan tinggi hanya mencapai $16,5 \%$ yang terdiri dari $25 \%$ dari kelompok kasus dan $8 \%$ pada kelompok kontrol.

Penjelasan hubungan kesehatan dengan pendidikan dan kesehatan adalah bahwa pendidikan menghasilkan manfaat yang kemudian mempengaruhi penerima untuk menghasilkan kesehatan lebih baik. Pendidikan memberikan kesempatan untuk mempelajari lebih lanjut tentang kesehatan dan risiko kesehatan. Orang-orang dengan pendidikan tinggi cenderung lebih peduli dengan isu-isu kesehatan dan lebih mudah menerima kampanye terkait pendidikan kesehatan. Kemudian, informasi yang terserap tersebut akan menjadi pertimbangan bagi seseorang untuk memilih gaya hidup yang sehat guna mencegah atau mengelola penyakitnya (National Center fo Chronic Desease Prevention and Health Promotion, 2017).

\section{Status Perkawinan}

Berdasarkan hasil analisis diperoleh bahwa pasien yang janda/duda berisiko 2,5 kali lebih tinggi untuk menjalani Hemodialisis dibandingkan dengan pasien yang belum pernah kawin $(\mathrm{OR}=2,500 ; 95 \% \mathrm{CI}=0,389$ $16,049)$. Sedangkan pasien yang berstatus kawin berisiko 1,26 kali lebih tinggi dibandingkan pasien yang belum pernah kawin $(\mathrm{OR}=1,265 ; 95 \% \quad \mathrm{CI}=0,559-2,865)$. Nilai $p=0,334$ artinya status perkawinan tidak 
memiliki pengaruh signifikan terhadap pasien Hemodialisis.

\section{Pekerjaan}

Berdasarkan hasil analisis diperoleh bahwa pasien yang pekerjaannya membutuhkan kemampuan berfikir 3,2 kali lebih tinggi untuk menjalani Hemodialisis dibandingkan dengan kelompok yang bekerja di rumah atau pensiunan $(\mathrm{OR}=3,22 ; 95 \%$ $\mathrm{CI}=0,93-11,22)$. Nilai $\mathrm{p}=0,066$ artinya pekerjaan tidak memiliki pengaruh signifikan terhadap Hemodialisis. Akan tetapi pada penelitian lain menyebutkan bahwa pekerjaan yang berhubungan aktivitas fisik memiliki peluang lebih besar untuk mengalami gagal ginjal. Para petani memiliki 3 kali lebih tinggi untuk mengalami gagal ginjal dan menjalani hemodialisis dibandingkan dengan karyawan pada perusahaan yang tidak banyak beraktivitas fisik (Emily Zimmeman and Steven H.Woolf, 2014).

Pada penelitian sebelumnya, menyebutkan bahwa aktifitas fisik berhubungan dengan usia dan aktifitas fisik responden. Aktifitas fisik yang berat akan membuat responden membutuhkan energi lebih besar, keseimbangan nutrisi serta rentan terhadap kondisi seperti kelelahan, dehidrasi dan kram otot. Semakin besar umur responden, semakin tinggi potensi mereka mengalami kondisi tersebut. Hal ini akan berujung pada cara responden menjaga staminanya, seperti pada faktor risiko yang ditemukan pada penelitian Delima,dkk di Jakarta yaitu dengan mengkonsumsi multivitamin, minum obat anti nyeri, minum jamu pegal linu, dan mengkonsumsi minuman yang menyegarkan seperti minuman bersoda, minuman isotonis, dan minuman berenergi guna mendapatkan kesegaran instan setelah kelelahan bekerja. (Delima, dkk, 2014).

Menurut Badan Pusat Staitistik tahun 2018, tiga lapangan pekerjaan utama di Indonesia adalah pertanian, kehutanan dan perikanan sebesar 30,46\%; perdagangan sebesar 18,53\% dan industri pengolahan sebesar $14,11 \%$. Pekerjaan tersebut termasuk kepada pekerjaan lapangan, yang lebih banyak membutuhkan aktivitas fisik (Rotich Joyce Cherono, 2017). Hal ini menunjukkan bahwa sebagian besar pekerjaan penduduk Indonesia adalah kelompok pekerjaan yang membutuhkan otot. Oleh karena itu, kelompok pekerjaan pada penelitian tidak dapat dijadikan sebagai faktor risiko gagal ginjal.

\section{Kebiasaan Merokok}

Berdasarkan hasil analisis diperoleh bahwa pasien yang sudah berhenti merokok cenderung 3,7 kali lebih banyak menjalani Hemodialisis daripada pasien yang tidak merokok $(\mathrm{OR}=3,796$; 95\% $\mathrm{CI}=1,692-8,514)$. Nilai $\mathrm{p}=0,001$ artinya merokok memiliki pengaruh terhadap Hemodialisis. Pada penelitian ini, kelompok yang berhenti merokok adalah kelompok pasien yang memilih berhenti merokok setalah mereka divonis memiliki penyakit. Terutama pada kelompok kasus, responden memilih untuk langsung berhenti merokok ketika mereka divonis gagal ginjal, dan harus menjalani hemodialisis sepanjang sisa hidupnya. Hal tersebut sangat berbeda dengan responden kelompok kontrol yang memilih berhenti secara perlahan.

Sudah banyak penelitian yang menyebutkan bahwa kebiasaan merokok merupakan salah satu faktor risiko PGK. Bahkan memulai aktivitas merokok $\leq 60$ menit setelah bangun tidur dapat meningkatkan potensi gagal ginjal. Risiko meningkat seiring dengan bertambahnya jumlah batang rokok yang dihisap, karena paparan zat kimia yang diserap tubuh karena merokok juga akan bertambah. Di samping itu, tidak ada hubungan antara jenis rokok dengan potensi, semua jenis rokok memilki potensi yang sama dalam menimbulkan kerusakan ginjal. Nikotin yang terkandung dalam rokok mengalami proses metabolisme sebagian besar di hati dan ginjal. Nikotin yang berada pada ginjal akan 
memberatkan kerja ginjal yang apabila terus terakumulasi akan menyebabkan gangguan bahkan kerusakan pada ginjal (BPS, 2018).

Pada sebuah penelitian telah dilihat perubahan biokimia yang mencerminkan fungsi ginjal selama merokok. Fungsi ginjal dipengaruhi secara negatif karena rokok. Hal tersebut ditunjukkan dengan peningkatan kreatinin serum, urea dan terjadi penurunan serum asam urat. Ketinggian kreatinin dan urea ini lah yang dapat mempengaruhi filtras glomerulus, hingga kemudian mengakibatkan gangguan pada ginjal (Stengel,B. Et al, 2003).

\section{Riwayat Penyakit Berisiko}

Berdasarkan hasil analisis diperoleh bahwa pasien yang memiliki riwayat penyakit berisiko terdahulu (seperti hipertensi, diabetes, anemia, infeksi saluran kemih, dan sebagainya) berisiko 81 kali untuk menjalani Hemodialisis daripada pasien yang tidak memiliki riwayat penyakit $(\mathrm{OR}=81,81 ; 95 \%$ $\mathrm{CI}=32,34-206,96)$. Nilai $\mathrm{p}=0,000$ artinya riwayat penyakit memiliki berpengaruh terhadap Hemodialisis. Penyakit yang paling banyak berpengaruh adalah penyakit kardiovaskular dan diabetes (Munzir M, dkk, 2015).

Penyakit kardiovaskular mencakup semua penyakit dan kondisi jantung dan pembuluh darah, seperti arteri dan vena. Kondisi yang paling umum seperti serangan jantung, gagal jantung dan stroke. Hubungan penyakit kardiovaskular dengan gagal giinjal saling berkaitan satu sama lain. Penderita diabetes dan/atau penyakit kardiovaskular berisiko lebih tinggi terkena gagal ginjal, sedangkan penderita PGK memiliki kemungkinan dua puluh kali lipat meninggal akibat serangan jantung atau stroke dari pada kemungkinan mereka menjalani hemodialisis. Penyakit ini seperti mata rantai yang saling berkaitan. Apabila tubuh tidak dapat mengontrol kadar mineral tertentu, seperti kalium dan garam maka irama jantung akan menjadi tidak normal. Terlalu banyak garam dapat meningkatkan tekanan darat meningkatkan tekanan darah. Tekanan darah yang tinggi (hipertensi) dapat menyebabkan kerusakan ginjal dan kerusakan dapat menyebabkan darah tinggi (Munzir M, dkk, 2015).

Diabetes dapat merusak penyaring ginjal yang menyebabkan diabetes nefropati. Sekitar sepertiga dari penderita diabetes mengalami perkembangan hingga terjadi ginjal nefropati. Diabetes juga dapat merusak saraf di banyak bagian tubuh. Apabila kandung kemih terpengaruh, penderita akan mengalami kesulitan mengeluarkan ai seni. Jika urin menumpuk di kandung kemih, tekanan dapat membuatnya kembali mengalir ke ginjal, mengakibatkan gangguan dan kerusakan pada ginjal. Diabetes dapat menyebabkan urin memilki kadar gula yang tinggi, dan hal ini akan mendorong pertumbuhan bakteri sehingga meningkatkan potensi infeksi. Penderita diabetes berisiko 2,5 kali lebih besar mengalami PGK dibandingkan yang tidak diabetes (Kidney Health Autralia, 2015).

Sebagai penyakit yang disebut sebagai "silent disease", penyakit ginjal sering kali tidak menimbulkan gejala. Penurunan fungsi ginjal secara tiba-tiba disebut dengan gagal ginjal (Australian Institute of Health and Welfare, 2005). Berdasarkan hasil analisis diperoleh bahwa pasien yang memiliki gejala sebelum Hemodialisis (seperti infeksi ginjal dan penyakit ginjal bawaan) berisiko 8,6 kali lebih tinggi untuk menjalani Hemodialisis dibandingkan pasien yang tidak memiliki gejala sebelum hemodialisis $(\mathrm{OR}=8,61 ; 95 \%$ $\mathrm{CI}=1,06-70,170)$. Nilai $\mathrm{p}=0,035$ artinya gejala sebelum Hemodialisis memiliki pengaruh signifikan terhadap Hemodialisis. Dari 100 pasien hemodialisis, hanya 8 yang menunjukkan gejala seperti susah buang air kecil, air seni berbusa, dan muncul darah saat buang air besar. Kebanyakan responden hanya menyebutkan mereka hanya merasa lelah, dan saat diperiksa ke rumah sakit sudah terdiagnosa gagal ginjal. 
PGK memang diketahui sebagai penyakit yang tidak memiliki gejala hingga berada pada tahap akhir penyakit. Kebanyakan penderita tidak mengetahui bahwa mereka memiliki masalah ginjal pada tahapan awal penyakit. Oleh karena itu, deteksi awal PGK sangat diperlukan guna mencegah perkembangan penyakit serta menghindari perlunya dialisis dan transplantasi. Selain itu, karena penyakit ginjal berkaitan dengan penyakit kardiovaskular dan diabetes, perawatan dini diharapkan dapat mengurangi risiko kematian akibat penyakit kardiovaskular dan diabetes pada pasien (Eva Sulistiowati dan Sri Idaiani, 2015).

\section{Riwayat Konsumsi Obat / Jamu Cespleng}

Berdasarkan hasil analisis diperoleh bahwa pasien yang mengkonsumsi obat/jamu dengan efek cepat berisiko 3,9 kali lebih tinggi untuk menjalani Hemodialisis dibandingkan pasien yang tidak mengkonsumsi obat/jamu tersebut $(\mathrm{OR}=3,927 ; 95 \% \mathrm{CI}=1,964-7,855)$. Nilai $p=0,000$ artinya mengkonsumsi obat/jamu cespleng memiliki pengaruh signifikan terhadap Hemodialisis. Ini menunjukkan bahwa $39 \%$ responden kelompok kasus menggunakan obat/jamu tradisional untuk menyembuhkan penyakit sebelum mereka menjalani hemodialisis. Sebagian besar dari responden, terutama kelompok usia di atas 40 tahun mengaku bahwa mengkonsumsi jamu sudah menjadi kebiasaan dan tradisi. Tidak hanya untuk menghilangkan penyakit atau keluhan tertentu, namun sudah menjadi kebiasaan dalam menjaga stamina dan kesehatan sehari-hari. Responden bahakn tidak mempermasalahkan apakah jamu yang dikonsumsi sudah memiliki izin edar atau tidak, karena merasa merupakan kebiasaan turun temurun. Disamping itu, mereka dapat melakukan permintaan khusus untuk mendapatkan kahsiat yang lebih baik dengan efek kerja yang lebih cepat. Hal ini yang kemudian memunculkan spekulasi bahwa, obat/jamu yang dibuat secara khusus ini diduga mengandung bahan kimia obat tertentu.

Penggunaan jamu sebagai alternatif pada masyarakat secara umum termasuk tinggi (58\%) (Restu Pranandari dan Woro Supadmi, 2015). Sebagian masyarakat masih mengkonsumsi jamu untuk menjaga kesehatan dan menyembuhkan penyakit. Konsumsi masyarakat terhadap jamu paling tinggi ditemukan pada kelompok ekonomi rendahmenengah (pendapatan $<5$ jt/bulan), sebanyak $83 \%$. Penyebab utamanya penyebabnya adalah faktor sosial, harga dan budaya. Obat/jamu tradisional cenderung memiliki harga yang relatif jauh di bawah pengobatan modern, dan dengan pemasaran yang baik mereka akan lebih memilih mengkonsumsi obat/jamu. Meskipun bahaya penggunaannya secara terus menerus belum diteliti lebih lanjut, akan tetapi banyak praktisi kesehatan yang berpendapat bahwa mengkonsumsi obat/jamu tradisional dengan efek cesplang memiliki potensi menimbulkan masalah ginjal karena pengaturan dosisnya yang belum jelas (Dr. Randi Chen, 2018).

\section{Kebiasaan Minum}

Berdasarkan hasil analisis diperoleh bahwa pasien yang mengkonsumsi minuman berisiko (seperti minuman tinggi gula dan mineral, kopi/teh/coklat, dan alkohol) berisiko 2,4 kali lebih tinggi untuk menjalani Hemodialisis dibandingkan pasien yang tidak mengkonsumsi minuman berisiko tersebut (OR=2,43; 95\% CI=0,61-9,69). Nilai $\mathrm{p}=0,331$ artinya mengkonsumsi minuman berisiko tidak memiliki pengaruh signifikan terhadap Hemodialisis. Kebiasaan minum minuman berisiko pada kelompok kasus dan kontrol hampir sama. Minum minuman seperti teh, kopi dan coklat menjadi favorit responden, karena teh dan kopi merupakan tanaman komersial utama dan memiliki harga yang terjangkau di banding minuman soda, minuman energi maupun minuman alkohol. Hal ini menyebabkan frekuensi 
mengkonsumsi teh menjadi meningkat, setiap hari.

Konsumsi minuman tinggi gula seperti soda memiliki risiko yang lebih besar dibanding konsumsi kopi dan teh. Beberapa penelitian kecil telah meneliti efek dari konsumsi soda pada kemih sukarelawan sehat dengan hasil yang tidak konsisten, akan tetapi ditemukan adanya hubungan antara minuman manis dengan munculnya batu ginjal. Hal ini bisa terjadi karena minuman manis mengandung fruktosa, dimana fruktosa sudah terbukti sebagai salah satu faktor pembentuk batu ginjal. Pada penelusuran responden mengaku menyukai minuman bersoda karena sensasi rasa segar yang ditimbulkannya. Penelitian oleh praktisi kesehatan menemukan bahwa mengkonsumsi minuman beverage seperti teh dan kopi dapat mempengaruhi fungsi ginjal, walau masih banyak yang tidak setuju karena nilainya yang rendah (33.9\%). Mengkonsumsi minuman berisiko tidak dapat dibuktikan sebagai faktor risiko terjadinya hemodialisis karena sebagian besar masyarakat Indonesia senang mengkonsumsi minuman tersebut dan berhubungan dengan budaya (Adriati, dan R.M Teguh Wahjudi, 2016).

Berdasarkan hasil analisis diperoleh bahwa pasien yang mengkonsumsi air 1-4 gelas per hari berisiko 1,6 kali untuk menjalani Hemodialisis dibandingkan pasien yang konsumsi air lebih dari 8 gelas per hari $(\mathrm{OR}=1,61 ; \quad 95 \% \quad \mathrm{CI}=0,71-3,65)$. Artinya banyaknya konsumsi air merupakan faktor protektif terhadap kejadian Hemodialisis. Nilai $p=0,080$ berarti jumlah konsumsi air per hari tidak memiliki pengaruh signifikan terhadap Hemodialisis.

Ginjal berfungsi mengatur keseimbangan cairan tubuh. Selain itu ginjal menyaring limbah dari darah dan dapat berfungsi lebih efisien dengan adanya pasokan cairan yang berlimpah. Asupan air yang tinggi akan meningkatkan pembersihan natrium dan urea, dan peningkatan asupan air adalah terapi terbanyak digunakan dan efektif untuk mencegah batu ginjal. Dalam kondisi hidrasi rendah, ginjal akan menghasilkan lebih banyak urin pekat dan ditemukan beberapa bukti bahwa konsentrasi urin yang lebih tinggi berkontribusi untuk hiperfiltrasi glomerulus dan pengembangan albuminuria. Penurunan volume cairan dapat membuat ginjal rentan cidera, dan akumulasi berulang akan mempercepat perkembangan PGK. Di samping itu, perlu diperhatikan jumlah mineral yang diasup dalam minuman, karena kekurangan asupan mineral seperti fosfor, kalium, besi dan seng dkaitkan dengan peningkatan PGK (Jessica M., et al, 2013).

Berdasarkan sumber air minum , diperoleh hasil bahwa pasien yang sumber air minumnya air sumur berisiko 1,2 kali lebih tinggi untuk menjalani Hemodialisis dibandingkan pasien yang sumber air minumnya bukan air sumur $(\mathrm{OR}=1,24 ; 95 \%$ $\mathrm{CI}=0,65-2,35$ ). Nilai $\mathrm{p}=0,624$ artinya sumber air minum tidak memiliki pengaruh signifikan terhadap Hemodialisis. Air sumur pada umumnya mengandung metal terlarut seperti $\mathrm{Na}, \mathrm{Mg}, \mathrm{Ca}$, dan Fe. Apabila terakumulasi banyak di dalam tubuh akan mempengaruhi tubuh secara negatif. Kelebihan kalsium akan menyebabkan hiper-paratyroidsm, batu ginjal dan kerusakan jaringan otot. Kelebihan magnesium akan mempengaruhi syaraf otot dan otot jantung. Orang yang mengkonsumsi air yang banyak mengandung kapur tinggi akan menjadi predisppossi pembentukan batu pada saluran kencing. Pada penelitian ini tidak ditemukan adanya hubungan antara sumber air minum dari air sumur dengan yang tidak, berarti air sumur yang dikonsumsi masih memiliki kandungan yang baik bagi Kesehatan (Jeewo Kim, etc, 2018).

\section{Kebiasaan Makan}

Berdasarkan hasil analisis diperoleh bahwa pasien yang mengkonsumsi makanan tinggi garam berisiko 1,8 kali untuk menjalani Hemodialisis dibandingkan pasien yang tidak 
mengkonsumsi makanan tinggi garam $(\mathrm{OR}=1,81 ; 95 \% \mathrm{CI}=0,51-6,38)$. Nilai $\mathrm{p}=0,537$ artinya mengkonsumsi makanan tinggi garam tidak memiliki pengaruh signifikan terhadap Hemodialisis. Sedangkan pasien yang mengkonsumsi makanan tinggi garam dan lemak berisiko 0,6 kali untuk menjalani Hemodialisis dibandingkan pasien yang tidak mengkonsumsi makanan tinggi garam dan lemak $(\mathrm{OR}=0,61 ; 95 \% \mathrm{CI}=0,23-1,64)$. Nilai $\mathrm{p}=0,459$ artinya mengkonsumsi makanan tinggi garam dan lemak tidak memiliki pengaruh signifikan terhadap Hemodialisis.

Pasien yang mengkonsumsi daging olahan berisiko 0,6 kali lebih tinggi dibandingkan pasien yang tidak mengkonsumsi daging olahan untuk menjalani Hemodialisis $\quad(\mathrm{OR}=0,58 ; 95 \% \quad \mathrm{CI}=0,293$ $1,16)$. Nilai $\mathrm{p}=0,168$ artinya mengkonsumsi daging olahan tidak memiliki pengaruh signifikan terhadap Hemodialisis. Ketika mengkonsumsi makanan tinggi protein seperti lemak dan daging olahan, maka akan muncul limbah protein yang akan disaring ginjal. Jutaan nefron akan bekerja untuk mengeluarkan limbah tersebut dari tubuh. Konsumsi yang berlebihan akan mengakibatkan ginjal bekerja lebih keras dan ginjal yang tidak sehat akan kehilangan kemampuannya untu membuang sisa protein dan akan menumpuknya di dalam darah.

Pada analisis mulivariat ditemukan perbedaan yang signifikan pada odds rasio. Hal ini dapat terjadi karena standar deviasi yang terlalu tinggi dan sistem sampling yang kurang acak dengan jumlah sampel yang kurang sehingga dapat meningkatkan standar error yang otomatis akan meningkatkan Confident Internval (CI) pada penelitian. CI adalah interval nilai populasi yang diyakini benar sehingga ditunjukkan dalam bentuk batas bawah (lower) dan batas atas (upper) dalam estimasi nilai rata-rata populasi. Pada proses pengambilan sampel sudah dilakukan acak, akan tetapi RS-X merupakan rumah sakit rujukan nasional, sehingga terdapat banyak pasien dengan berbagai masalah kesehatan yang kompleks, sehingga perlu dilakukan proses penyeragaman (matching) sampel guna mendapatkan hasil yang lebih baik. Pada penelitian ini sangat sulit untuk menemukan responden yang benar-benar setara guna menghasilkan hasil penelitian yang lebih presisi. Hal ini yang kemudian mengakibatkan angka CI pada riwayat penyakit menjadi sangat besar.

Sebagai rumah sakit umum pusat, RS-X merupakan salah satu dari rumah sakit rujukan. Kebanyakan responden yang menjalani hemodialisis di RS-X adalah pasien dengan riwayat penyakit tertentu dengan beberapa komplikasi penyakit. Selain itu, pada penelitian sudah terlihat bahwa pasien yang menjalani hemodialisis di RS-X bukan hanya warga sekitar rumah sakit melainkan berasal dari Provinsi DKI Jakarta, Banten dan Jawa Barat. Dengan demikian dapat disimpulkan bahwa riwayat penyakit sebagai faktor risiko terkuat yang berhubungan dengan kejadian hemodialiasis adalah hal yang dapat dibuktikan.

Menurut Riskesdas 2013, prevalensi faktor risiko PGK antara lain umur, riwayat penyakit (hipertensi, diabetes, dan obesitas). Prevalensi pada laki-laki lebih tinggi dari pada perempuan, prevalensi lebih tinggi pada tingkat pendidikan rendah dan pekerja buruh. Menurut penelitian sebelumnya di RS-X, ditemukan faktor risiko seperti umur yang semakin meningkat, kurangnya minum air putih, sering mengkonsumsi minuman energi drink dan soda, serta riwayat penyakit yang berhubungan dengan ginjal. Hal tersebut agak berbeda dengan penelitian, yang kemungkinan disebabkan oleh perbedaan metode yang digunakan (Infodatin, 2017).

\section{KESIMPULAN}

Pada faktor-faktor yang ditemukan, sebagian besar adalah faktor risiko yang dapat diubah karena berhubungan dengan 
kebiasaan/prilaku seseorang seperti konsumsi obat/ jamu tradisional, kurang minum air, kebiasaan mnum beresiko, kebiasaan merokok dan kebiasaan makan. Semua faktor tersebut dapat dihindari guna menurunkan potensi kerusakan ginjal. Berdasarkan hasil analisis regresi logistik ganda, dapat disimpulkan bahwa variabilitas dari terjadinya hemodialisis dapat dijelaskan oleh 7 variabel (umur, riwayat penyakit, konsumsi obat/jamu, konsumsi air dalam sehari, kebiasaan minum berisiko, sumber air minum, dan kebiasaan makan tinggi garam) sebesar 83,7\%, sedangkan $16,3 \%$ sisanya dijelaskan oleh variabel lain (selain 7 variabel tersebut).

\section{UCAPAN TERIMAKASIH}

Peneliti mengucapkan terimakasih kepada berbagai pihak yang atas bantuannya, sehingga penelitian dapat diselesaikan dengan baik, terutama kepada rekan-rekan mahasiswa dan Magister Farmasi Universitas Pancasila

\section{DAFTAR PUSTAKA}

Adriati, dan R.M Teguh Wahjudi. (2016) Tingkat penerimaan penggunaan jamu sebagai alternatif penggunaan obat modern pada masyarakat ekonomi rendah-menengah dan atas. Fakultas Kedokteran, Universitas Airlangga. Surabaya.

Aisyah, Andri Dwi Hernawan, Abduh Ridha. (2015) Perilaku Merokok Sebagai Faktor Yang Berisiko Terhadap Kejadian Gagal Ginjal Kronik. Jurnal Mahasiswa Peneliti Kesehatan Fakultas Ilmu Kesehatan Masyarakat Universitas Muhammadyah Pontianak. Pp 70-83

Australian Institute of Health and Welfare. (2005) Chronic kidney disease in
Australia. Australia: Australian Institute of Health and Welfare.

Badan Penelitian dan Pengembangan Kesehatan. (2013). Kementerian Kesehatan. Jakarta: Laporan hasil Riset Kesehatan dasar.

Badan Pusat Statistik. (2018). Berita Resmi Statistik : Keadaan Ketenagakerjaan Indonesa

Delima, Emiliana Tjitra, Lusianawati Tana, Frans Suharyanto Halim,et all. (2017). Faktor risiko penyakit ginjal kronik: Studi kasus kontrol di empat rumah sakit di Jakarta tahun 2014. Buletin Penelitian Kesehatan, 45 (1), pp 17-26.

Dr. Randi Chen. (2018). Slowing the Progression of Chronic Kidney Disease. American Kidney Fund.

Emily Zimmeman, Steven H.Woolf. (2014). Virginia Commonwealth University: Understanding the Relationship Between Education and Health.

Eva Sulistiowati, Sri Idaiani. (2015) Faktor Risiko Penyakit Ginjak Kronik Berdasarkan Analisis Cross-Sectional Data Awal Studi Kohort Penyakit Tidak Menular Penduduk Usia 25-65 Tahun di Kelurahan Kebun Kalapa, Kota Bogor Tahun 2011. Pusat Teknologi Terapan Kesehatan dan Epidemiologi Klinik.

Indonesia Investment. (2019). Jakarta: Laporan Kependudukan ; diakses dari https://www.indonesiainvestments.com/id/budaya/penduduk/it em67 pada tanggal 10 Januari 2019

Infodatin Pusat data dan informasi kementrian kesehatan RI. (2017) Situasi penyakit 
ginjal kronis. Jakarta : Kementerian Kesehatan.

Munzir M, M.Ahmed, et al. (2015) The Effect of Smoking Cigarette on Kidney Functions Among Sundaes Peoples. Internationan Journal of Development Research, 5 (5), pp.4473-4475.

National Center fo Chronic Desease Prevention and Health Promotion. (2017) National Chronic Kidney Desease Fact Sheet: Division of Diabetis Translation.

Pietro Manuel Ferraro, Eric N. Taylor, Giovanni Gambaro, dan Gary C. Cuthan. (2013) Soda and Other Beverages and the Risk of Kidney Stones. Clin J Am Soc Nephrol, 8(8), pp 1389-1395.

Restu Pranandari, Woro Supadmi. (2015). Faktor risiko gagal ginjal kronik di unit hemodialisis RSUD Wates Kulon Progo. 2015, Majalah Farmasetik, 2(2), pp, 316320.
Rotich Joyce Cherono. (2017) The Prevalence and Risk Factor for Chronic Kidney Diseases in Kerincho Country,Kenya. American Research Institute for Policy Development, International Journal of Nursing, 4 (2) pp 90-105.

Stengel,B. Et al. (2003). Lifestyle factor, Obesity and the Risk of Chronic Kidney Disease. 2003. Epidemiology, 14 (4), pp 87-479

The Australian Kidney Foundatiion Trading as Kidney Health Autralia.(2015) Australia: Linking Kidney Disease Cardiovascular Disease and Diabetes.

10th Report of Indonesan renal registry, Indonesia; (2017). Diakses dari https://www.indonesianrenalregistry.org/ data/IRR\%202017\%20.pdf. 